Marquette University

e-Publications@Marquette

2016

\title{
Chronic Exposure to Triclosan Sustains Microbial Community Shifts and Alters Antibiotic Resistance Gene Levels in Anaerobic Digesters
}

\author{
Daniel Elliott Carey \\ Marquette University \\ Daniel Zitomer \\ Marquette University, daniel.zitomer@marquette.edu \\ Anthony D. Kappell \\ Marquette University, anthony.kappell@marquette.edu \\ Melinda J. Choi \\ Marquette University \\ Krassimira R. Hristova \\ Marquette University, krassimira.hristova@marquette.edu
}

See next page for additional authors

Follow this and additional works at: https://epublications.marquette.edu/civengin_fac

Part of the Civil Engineering Commons

\section{Recommended Citation}

Carey, Daniel Elliott; Zitomer, Daniel; Kappell, Anthony D.; Choi, Melinda J.; Hristova, Krassimira R.; and McNamara, Patrick J., "Chronic Exposure to Triclosan Sustains Microbial Community Shifts and Alters Antibiotic Resistance Gene Levels in Anaerobic Digesters" (2016). Civil and Environmental Engineering Faculty Research and Publications. 143.

https://epublications.marquette.edu/civengin_fac/143 


\section{Authors}

Daniel Elliott Carey, Daniel Zitomer, Anthony D. Kappell, Melinda J. Choi, Krassimira R. Hristova, and Patrick J. McNamara 


\title{
Chronic Exposure to Triclosan Sustains Microbial Community Shifts and Alters Antibiotic Resistance Gene Levels in Anaerobic Digesters
}

\author{
Daniel E. Carey \\ Department of Civil, Construction and \\ Environmental Engineering, \\ Marquette University, \\ Milwaukee, WI \\ Daniel H. Zitomer \\ Department of Civil, Construction and \\ Environmental Engineering, \\ Marquette University, \\ Milwaukee, WI \\ Anthony D. Kappell \\ Department of Biological Sciences, Marquette University, \\ Milwaukee, WI \\ Melinda J. Choi \\ Department of Civil, Construction and \\ Environmental Engineering,
}

Environmental Science: Processes \& Impacts, Vol 18, No. 8 (2016): pg. 1060-1067. DOI. This article is @ Royal Society of Chemistry and permission has been granted for this version to appear in e-Publications@Marquette. Royal Society of Chemistry does not grant permission for this article to be further copied/distributed or hosted elsewhere without the express permission from Royal Society of Chemistry. 
NOT THE PUBLISHED VERSION; this is the author's final, peer-reviewed manuscript. The published version may be accessed by following the link in the citation at the bottom of the page.

\author{
Marquette University, \\ Milwaukee, WI \\ Krassimira R. Hristova \\ Department of Biological Sciences, Marquette University, \\ Milwaukee, WI \\ Patrick J. McNamara \\ Department of Civil, Construction and \\ Environmental Engineering, \\ Marquette University, \\ Milwaukee, WI
}

Triclosan, an antimicrobial chemical found in consumer personal care products, has been shown to stimulate antibiotic resistance in pathogenic bacteria. Although many studies focus on antibiotic resistance pertinent to medical scenarios, resistance developed in natural and engineered environments is less studied and has become an emerging concern for human health. In this study, the impacts of chronic triclosan (TCS) exposure on antibiotic resistance genes (ARGs) and microbial community structure were assessed in lab-scale anaerobic digesters. TCS concentrations from below detection to 2500 mg kg- ${ }^{1}$ dry solids were amended into anaerobic digesters over 110 days and acclimated for $>3$ solid retention time values. Four steady state TCS concentrations were chosen (30-2500 mg kg-1). Relative abundance of $\operatorname{mex} B$, a gene coding for a component of a multidrug efflux pump, was significantly higher in all TCS-amended digesters (30 $\mathrm{mg} \mathrm{kg}^{-1}$ or higher) relative to the control. TCS selected for bacteria carrying tet $(\mathrm{L})$ and against those carrying erm $(\mathrm{F})$ at concentrations which inhibited digester function; the $\mathrm{pH}$ decrease associated with digester failure was suspected to cause this selection. Little to no impact of TCS was observed on int/1 relative abundance. Microbial communities were also surveyed by high-throughput 16S rRNA gene sequencing. Compared to the control digesters, significant shifts in community structure towards clades containing commensal and pathogenic bacteria were observed in digesters containing TCS. Based on these results, TCS should be included in studies and risk

Environmental Science: Processes \& Impacts, Vol 18, No. 8 (2016): pg. 1060-1067. DOI. This article is @ Royal Society of Chemistry and permission has been granted for this version to appear in e-Publications@Marquette. Royal Society of Chemistry does not grant permission for this article to be further copied/distributed or hosted elsewhere without the express permission from Royal Society of Chemistry. 
NOT THE PUBLISHED VERSION; this is the author's final, peer-reviewed manuscript. The published version may be accessed by following the link in the citation at the bottom of the page.

assessments that attempt to elucidate relationships between chemical stressors (e.g. antibiotics), antibiotic resistance genes, and public health.

\section{Environmental impact}

Triclosan in an antimicrobial agent found ubiquitously in municipal wastewater. Triclosan is not an antibiotic, but it has been shown to impact antibiotic resistance in pure cultures. This work investigates the impact of chronic exposure to triclosan on antibiotic resistance in anaerobic digesters. Anaerobic digestion contains a thick and diverse community of microbes that could be susceptible to developing antibiotic resistance after exposure to triclosan. The biosolids from anaerobic digesters are often land applied. Transport and fate of microbes from these systems should be further quantified to fully understand the role of triclosan on human health. The impact of triclosan on antibiotic resistance is not limited to clinical settings and needs to be elucidated in the environment as well.

\section{Introduction}

Antibiotic resistance has been recognized as a major threat to public health and involves the high use of antibiotics, which creates an opportunity for bacteria to become resistant. ${ }^{1,2}$ In addition to concern from the overuse of antibiotics, antimicrobials are a concern with regard to proliferation of antibiotic resistance. ${ }^{3}$ Antibiotics have specific inhibition mechanisms towards certain bacteria which make them useful for medical treatment; while antibiotics are considered antimicrobials, the term antimicrobial is a broad term used to describe chemicals that kill or inhibit microorganisms. Antimicrobials in personal care products are generally thought to be broad-spectrum inhibitory chemicals. ${ }^{4}$

Triclosan (TCS) is an antimicrobial found in multiple consumer products, including liquid hand soaps, lotions, toothpaste, plastics and many other personal care products. ${ }^{5}$ Resistance to TCS has been well documented in pathogenic bacteria. ${ }^{5,6}$ TCS has specific genetic targets within cells and inhibits fatty acid synthesis at low concentrations. ${ }^{7}$ Perhaps because of this specific inhibition, multiple species have 
developed resistance to TCS. Common resistance mechanisms to TCS include $\mathrm{fab} /$ modification, membrane alteration, or active efflux. ${ }^{4,8-11}$

TCS is an especially concerning antimicrobial because resistance to TCS can also result in cross-resistance to antibiotics. ${ }^{6,12}$ Multiple studies with various species have shown exposure to TCS can result in increased resistance to chloramphenicol, tetracycline and many other antibiotics. For example, cross-resistance to chloramphenicol developed from TCS exposure has been observed for $E$. coli, ${ }^{13} P$. aeruginosa, ${ }^{14}$ S. maltophilia, ${ }^{15}$ and $S$. enterica. ${ }^{16,17}$

TCS is widely detected in the environment and ubiquitous in wastewater treatment plants. It has further been linked to resistance in bacteria found in pipes, sinks, wastewater treatment effluent, activated sludge, anaerobic digestion, and streams. ${ }^{18-21}$ The majority of TCS entering a treatment plant sorbs to solids and passes through anaerobic digestion. Furthermore, TCS is persistent under anaerobic conditions. ${ }^{22-24}$ TCS also alters microbial community structures in anaerobic environments. ${ }^{25}$ Previous research demonstrated that TCS can select for mex $B$, a component of a multidrug efflux pump, in mixed anaerobic communities seeded with manure, but no research describes the impact of long-term chronic exposure to TCS in anaerobic communities seeded with municipal anaerobic digester sludge. ${ }^{25}$

The objective of this study was to determine if long-term TCS exposure resulted in sustained increases in relative abundance of antibiotic resistance genes (ARGs) and altered microbial community structure. Lab-scale digesters were seeded with municipal biosolids from anaerobic digesters, and the digesters were acclimatized to various elevated TCS concentrations. Digesters were operated under steady-state conditions for 6.5 solid retention time (SRT) values before quantification of ARGs. Steady-state samples were taken on 3 different days from triplicate digesters after the 6.5 SRT values and analyzed for the relative abundance of $\operatorname{mex} B, \operatorname{erm}(\mathrm{F}), \operatorname{tet}(\mathrm{L})$, and intl1. Samples for microbial community analysis were taken after 6.5 SRT values as well. 


\section{Experimental methods}

\section{Setup}

Lab-scale anaerobic digesters $(160 \mathrm{~mL}$ serum bottles with 50 $\mathrm{mL}$ working volume) were operated for 110 days. The digesters were fed synthetic primary sludge ( $3.6 \mathrm{~g} \mathrm{COD} / \mathrm{L}_{g} \mathrm{~d}, 10$ day SRT) daily with a syringe. Synthetic sludge was ground, sieved (40 mesh) dog food (Nutro-Natural Choice, Franklin, TN, USA) in a nutrient medium (see ESI S1†). The digesters were seeded with municipal anaerobic digester biomass from South Shore Water Reclamation Facility (Oak Creek, WI, USA).

\section{TCS digester concentrations}

A total of 15 digesters ( 5 sets in triplicate) were operated for 45 days at the background concentration in the biomass (measured to be approximately $30 \mathrm{mg} \mathrm{kg}^{-1}$ in seed) with the exception of the control which received no TCS. On Day 45 three sets of digesters were fed 'low', 'medium', and 'high' concentrations of TCS (see Fig. 1). The low concentration ( $100 \mathrm{mg} \mathrm{kg}^{-1}$ ) was between the $95^{\text {th }}$ percentile (62 $\mathrm{mg}$ $\mathrm{kg}^{-1}$ ) and 98th percentile (124 $\mathrm{mg} \mathrm{kg}^{-1}$ ) TCS biosolids concentration observed during an EPA survey of municipal biosolids. ${ }^{26}$ Medium (850 $\mathrm{mg} \mathrm{kg}^{-1}$ ) and high ( $2500 \mathrm{mg} \mathrm{kg}^{-1}$ ) concentrations correlated to the concentrations of TCS which inhibited methane production rate by $10 \%$ and $50 \%$, respectively, based on a previous anaerobic toxicity assay using the seed biomass (see ESI S2 + ). All concentrations in the biosolids were confirmed by Liquid Chromatography-Mass Spectroscopy (see ESI S3†). TCS was added to the synthetic primary sludge by mixing an appropriate amount of TCS dissolved in methanol to dog food which was then evaporated to dryness to remove methanol.

\section{Analytical methods}

The $\mathrm{pH}$ was measured using a probe and meter (Orion 4 Star, Thermo, Waltham, MA, USA). Volatile fatty acids (VFAs) and methane percent in biogas were measured by gas chromatography (7890A, 
Agilent Technologies, Irving, TX, USA). ${ }^{27}$ Carbon dioxide concentration in biogas was estimated by calculating (100\% - methane\%).

\section{DNA extraction}

DNA was extracted using a commercial kit (MP Fast DNA SPIN kits, Solon, Ohio) modified with freeze thaw cycling to improve yield..$^{25}$ Extraction was performed on biomass samples collected on Day 45, 105,107 , and 110 from each digester. Approximately $2 \mathrm{~mL}$ of biomass suspension was used for extraction.

\section{qPCR for resistance gene and intl1 quantification}

Quantitative polymerase chain reaction ( $\mathrm{qPCR}$ ) was performed for select resistance genes. The mexB gene encodes a chromosomal efflux pump in Pseudomonas aeruginosa; ${ }^{46}$ mexB has been indicated to be found on plasmids in activated sludge and on annotated, yet unpublished, natural plasmids. ${ }^{54}$ Further, mex $B$-like genes have been found in many species. ${ }^{55}$ This gene was targeted because it has been previously linked with microbial TCS resistance. ${ }^{25,28}$ A tetracycline resistance gene, tet $(\mathrm{L})$, was also quantified as it encodes for an efflux pump. ${ }^{29}$ As a control, erm(F) was quantified since TCS concentration was not suspected to influence relative abundance of this gene because the gene specifically targets macrolides, lincosamides, and streptogramin. ${ }^{30}$ Finally, int 1 , which is associated with class 1 integrons that facilitate the horizontal exchange of resistance genes, was quantified. ${ }^{31}$ Specific primer sets, annealing temperatures, efficiencies and quantification limits are described in ESI section S4. ${ }^{\dagger}$

\section{$16 S$ rRNA gene sequencing}

Microbial community of each digester was determined by partial sequencing of the 16S rRNA genes using Illumina MiSeq Platform of samples from Day 45 and 110 as described previously (performed by MRDNA Molecular Research LP, Shallowater, TX). ${ }^{32}$ Briefly, amplification of the V4 region of the 16S rRNA gene was performed prior to Illumina sequencing. Sequences (30 000-100 000 per digester) were identified. Denoised sequences were binned in operational taxonomic units which had more than $97 \%$ similarity and

Environmental Science: Processes \& Impacts, Vol 18, No. 8 (2016): pg. 1060-1067. DOI. This article is @ Royal Society of Chemistry and permission has been granted for this version to appear in e-Publications@Marquette. Royal Society of Chemistry does not grant permission for this article to be further copied/distributed or hosted elsewhere without the express permission from Royal Society of Chemistry. 
classified using a database derived from GreenGenes, RDPII, and NCBI. Further details can be found in ESI S5.†

\section{Statistics}

The R Project for Statistical Computing program (V 3.1.2, Vienna, Austria) was used to produce non-parametric multidimensional scaled (NMDS) plots using the vegan package. Dual hierarchal clustering (using Kruskal-Wallis analysis of variance and cosine distances), heat mapping and Shannon diversity indices were also calculated using R-scripts. GraphPad Prism (V 6.04, La Jolla, CA) was utilized to perform ANOVA and $t$-tests.

\section{Results and discussion}

\section{Digester conditions}

The high concentrations of TCS in the high digesters substantially decreased methane production; approximately $80 \%$ of methane production was lost by Day 71 (Fig. 2). At this time, the concentration of TCS was $2340 \mathrm{mg} \mathrm{kg}^{-1}$. All other digesters continued producing methane at $67 \pm 8.7 \mathrm{~mL}$ methane per day. For the first 45 days, all digesters performed similarly and produced an average of 68 $\pm 6.8 \mathrm{~mL}$ of methane per day with the total biogas being $32 \pm 3.6 \%$ $\mathrm{CO}_{2}$.

For the digesters with high concentrations of TCS, a key acid utilizing bacterial (or perhaps archaeal) group was likely inhibited, resulting in a VFA buildup (Fig. 2). It should be noted that this toxic concentration ( $2500 \mathrm{mg} \mathrm{kg}^{-1}$ ) of TCS is much higher than observed in full-scale digesters, as the maximum TCS concentration found in the EPA biosolids survey was $133 \mathrm{mg} \mathrm{kg}^{-1}$. Environmental concentrations of TCS are unlikely to reduce methane production from full-scale anaerobic digesters. 
NOT THE PUBLISHED VERSION; this is the author's final, peer-reviewed manuscript. The published version may be accessed by following the link in the citation at the bottom of the page.

\section{Resistance genes}

The relative abundance of the mexB gene was statistically higher in every digester containing TCS compared to the control (Fig. $3)$. Increases in TCS did not correlate with increases in the relative abundance of $\operatorname{mex} B$; the relative abundance of $\operatorname{mex} B$ was not statistically different among the TCS-amended digesters (ANOVA, $p=$ $0.79)$. The mexB gene is of concern because it has been associated with resistance to TCS in more than one species. ${ }^{14,28}$ Furthermore, bacteria that have increased resistance to TCS through the MexAB efflux protein have cross-resistance to other antibiotics, including tetracycline, ciprofloxacin, trimethoprim, erythromycin and gentamicin. ${ }^{4}$ It should be noted that all digesters were seeded with municipal anaerobic biosolids used to stabilize municipal wastewater solids that already exhibited background levels of all resistance genes observed in the controls.

While a previous study proved that TCS could select for mexB in mixed anaerobic communities, the current study shows that TCS can select for this multidrug resistance gene during steady-state operation of municipal anaerobic digesters at concentrations observed in full-scale systems. ${ }^{25}$ The research described here demonstrates that sustained concentrations of TCS in municipal biosolids have a lasting impact on the relative abundance of mexB. This selection for mex $B$ could likely be due to a shift in microbial community structure (highlighted below in the Community structure section) that selected for bacteria that harbored the mexB gene. Concentrations of TCS employed in this study have been observed in full-scale, operating municipal anaerobic digesters (e.g. 30 and $100 \mathrm{mg} \mathrm{kg}^{-1}$ ). The widespread use of TCS and its ubiquitous detection in biosolids indicates that TCS is a continuous selective pressure in anaerobic digesters.

The relative abundances of tet $(\mathrm{L})$, coding for an efflux pump protein, were statistically similar for the control, background, low and medium digesters (ANOVA, $p=0.75$ ). The relative abundances of tet $(L)$ in the high digesters were over three orders of magnitude greater than in the other digesters. The high-TCS digesters functionally failed, ceasing to produce significant methane, and it is suspected that the acidic conditions selected for bacteria that harbored

Environmental Science: Processes \& Impacts, Vol 18, No. 8 (2016): pg. 1060-1067. DOI. This article is @ Royal Society of Chemistry and permission has been granted for this version to appear in e-Publications@Marquette. Royal Society of Chemistry does not grant permission for this article to be further copied/distributed or hosted elsewhere without the express permission from Royal Society of Chemistry. 
tet $(\mathrm{L})$ (the 16S rRNA copy numbers were not statistically different from other digesters on a volume basis; see ESI S7†). Some efflux pumps are capable of expelling small molecules (such as dyes and detergents) from within bacteria; ${ }^{33}$ likewise, the tet( $\left.L\right)$ pump may be able to expel toxic molecules which are produced under acidic conditions. Tet $(\mathrm{L})$ may also be intrinsic to a phyla that were highly selected for in the high-TCS digesters, that can survive at low $\mathrm{pH}$ conditions. In either case, TCS did not select for tet(L) under neutral $\mathrm{pH}$ operating conditions.

The erm(F) gene was not expected to be influenced by TCS because this resistance mechanism specifically resists macrolide compounds by methylating rRNA (the target of macrolide drugs). ${ }^{30}$ The digesters with $2500 \mathrm{mg} \mathrm{kg}$-1 of TCS had approximately two orders of magnitude less erm(F) than other digesters. The control, background, low and medium digesters had statistically similar relative abundances of erm(F) (ANOVA, $p$-value $=0.31$ ). Similar to the tet $(L)$ observations, the acidic conditions in the high-TCS digesters were suspected to be selecting against organisms containing erm(F).

The measured relative abundance of the integrase gene of the class 1 integron is independent of TCS concentration and bacterial population composition in functional digesters. No statistical difference was seen in the relative abundance of intl1 between the medium, low, background and control digesters (ANOVA, $p=0.86$ ). The high-TCS digesters had a statistically lower relative abundance of int/1 when compared to the control. Therefore, increasing the concentration of TCS, or the low pH, selected against bacteria with class 1 integrons, possibly indicating that resistance to TCS of the bacteria in the reactors was not integron based. Feasibly, the relative abundance of integrons could be sufficiently high in all digesters for significant horizontal gene transfer to occur in all digester conditions.

\section{Community structure}

On Day 110, when digesters had reached quasi-steady state (i.e., operating under the same TCS-loading conditions for $>3$ SRT values), the functioning TCS-amended communities, including the background, low, and medium level TCS communities, had diverged 
from the control communities (Fig. 4). The digesters containing a high concentration of TCS ( $2500 \mathrm{mg} \mathrm{kg}^{-1}$ ) diverged more from the control than the other digesters. The differences in communities is indicated by an NMDS plot of genus level data (ESI Fig. S6+) and a CCA plot of the OTU level data (ESI Fig. S8.2†). While the high digester set lost function, the digesters still maintained a microbial community which was producing VFAs (see Fig. 2), yet not producing methane.

The microbial community structures of the background, low, medium, and high TCS-amended digesters were also different from themselves between Days 45 and 110, but they remained in overlapping clusters on each day. On Day 45, the TCS-amended communities were not statistically different from the control, as indicated by $95^{\text {th }}$ percentile confidence intervals overlapping in Fig. 4 . The control communities at Day 45 were significantly different from the control communities on Day 110; this variation in community structure over time is common in biological systems and reinforces the importance of maintaining a control. ${ }^{34}$ TCS impacts microbial community structure even when the digesters maintain function as indicated by the TCS-amended communities not overlapping with the control communities on Day 110.

The community composition data suggest that, in uninhibited anaerobic digesters, TCS may be selecting for phyla and genera that contain pathogens and commensal organisms (Fig. 5). Pathogens and commensal organism are more likely to have been previously exposed to relatively high concentrations of TCS due to their interactions with people; therefore, these organisms may have certain resistance mechanisms. It should be noted that the seed biomass for these reactors came from an actual treatment plant which was ostensibly exposed to relatively lower levels of TCS and many other organic chemicals. In the control digesters, the relative abundance of the phyla Tenericutes, Fusobacteria and Spirochaetes was less than half of the relative abundance in the TCS-amended functioning digesters (Fig. 5 [left]). Pathogens and commensal organisms are found in each of these 3 phyla such as Mycoplasma (Tenericutes), Fusobacterium (Fusobacteria) and Borrelia (Spirochaetes), suggesting live TCS reactors enrich organisms which were previously exposed to high concentrations of TCS. ${ }^{35-38}$ Conversely, the control digesters had a

Environmental Science: Processes \& Impacts, Vol 18, No. 8 (2016): pg. 1060-1067. DOI. This article is @ Royal Society of Chemistry and permission has been granted for this version to appear in e-Publications@Marquette. Royal Society of Chemistry does not grant permission for this article to be further copied/distributed or hosted elsewhere without the express permission from Royal Society of Chemistry. 
higher relative abundance of the phyla Proteobacteria, Euryarchaeota, Acidobacteria, Thermotogae, and Elusimicrobia by at least 2 fold; these phyla may be sensitive to TCS. With the exception of Proteobacteria, these phyla are largely environmental bacteria or archaea and are not typically commensal organisms. ${ }^{39,40}$ The functioning digesters which contained TCS selected for several genera including Candidatus cloacomonas, Leptotrichia, Bacteroidales, topobium, Crocinitomix, Dermatophilus, Flavonifractor and others which were less abundant (Fig. 5 [right]). Leptotrichia, Bacteroidales, Atopobium, Dermatophilus, Flavonifractor are major genera containing organisms which are pathogenic and commensal. ${ }^{41-45}$

Without actually culturing or deeper sequencing of these bacteria, it is unclear if these organisms are pathogens or only phylogenetically related to pathogens. The community shift towards these clades could account for the selection of resistance genes like mexB.

The functioning digesters had similar dominant phyla as observed in analysis of full scale municipal digesters. ${ }^{47,48}$ These studies report Proteobacteria, Firmicutes, Bacteroidetes and Actinobacteria as the dominant phyla. Spirochaetes was more abundant than Actinobacteria in the current study, but detects were relatively high in the previous studies as well. ${ }^{47,48}$ Further, TCS selected against two abundant genera of methanogens (Methanoculleus and Methanosaeta), but not to the extent that methane production ceased in functioning digesters. Major syntrophic bacteria were not significantly affected (Smithella, Syntrophus, Syntrophomonas; data not shown). ${ }^{49}$

The microbial community structures of the high-TCS digesters were significantly different from the uninhibited digesters. The control and high-TCS digesters were clustered together in the dual hierarchal clustering of Fig. 5, however these communities were only similar on a phyla level. These communities were much different at a genera level (see ESI S6†) and OTU level (see ESI 8.2†). Microbial diversity in the high-TCS digesters was lower than in the functioning digester sets, yet the overall abundance of total bacteria was similar (see ESI S7t for 16S rRNA gene copy numbers). The Shannon diversity index (performed with genus level data) for the high-TCS digesters was 2.04

Environmental Science: Processes \& Impacts, Vol 18, No. 8 (2016): pg. 1060-1067. DOI. This article is @ Royal Society of Chemistry and permission has been granted for this version to appear in e-Publications@Marquette. Royal Society of Chemistry does not grant permission for this article to be further copied/distributed or hosted elsewhere without the express permission from Royal Society of Chemistry. 
\pm 0.12 , which is significantly lower than the index for control, background, low, and medium concentrations (all statistically similar, $3.49 \pm 0.14)$. The high-TCS digesters selected for the phyla Fibrobacteres, Actinobacteria, and Firmicutes. Firmicutes were the most abundant phylum in the TCS containing digesters. The tet $(\mathrm{L})$ gene is common to Gram-positive organisms; given that Firmicutes and Actinobacteria are Gram-positive, the increase in these phyla could explain the increase in the relative abundance of tet $(L)$. Other phyla that had over 10-fold lower concentrations in the high-TCS digesters than the functioning sets include ws3 (candidate division), Planctomycetes, Verrucomicrobia, Synergistetes, Fusobacteria, Tenericutes, Chloroflexi, and Spirochaetes. Furthermore, at the genus level, Succinivibrio, Atopobium, Olsenella, Flavonifractor, and Acetitomaculum were enriched in these same digesters. All of these genera are known commensal organisms with humans, cows, sheep and pigs. ${ }^{50-52}$ While all of these genera are known to be acid tolerant, four of the five are found in the ruminal or digestive tract (Atopobium is not associated with the rumen or digestive tract). The increased VFA concentrations in the high-TCS digesters provide conditions in which these clades can thrive. ${ }^{53}$

\section{Conclusions}

Previous research showed that TCS can select for resistance in anaerobic digesters stabilizing dairy manure after short-term exposure. This research demonstrated that constant amendment with TCS leads to sustained increases in the relative abundance of mex $B$ in anaerobic digesters seeded with municipal biosolids. This increase in the relative abundance of mexB occurred at environmentally relevant levels, indicating that the relative abundance of mexB is likely higher in full-scale municipal anaerobic digesters than it would be without TCS in the biosolids. In addition, other genes are selected for (tet $(\mathrm{L}))$ or against (erm(F)) if TCS inhibits the digesters function. TCS has little or no effect on the relative abundance of class 1 integrons. This research revealed that TCS selects for clades which contain pathogenic and commensal bacteria. These clades may have had previous exposure to antibiotics or antimicrobials, which affords the bacteria the opportunity to gain resistance mechanisms. To confirm this theory future work would need to culture bacteria or perform deeper

Environmental Science: Processes \& Impacts, Vol 18, No. 8 (2016): pg. 1060-1067. DOI. This article is @ Royal Society of Chemistry and permission has been granted for this version to appear in e-Publications@Marquette. Royal Society of Chemistry does not grant permission for this article to be further copied/distributed or hosted elsewhere without the express permission from Royal Society of Chemistry. 
sequencing from these TCS-amended biosolids to determine if pathogens are enriched.

TCS should be included with antibiotics in studies which address risk assessment of antibiotic resistance. Given the ubiquity of TCS and its relatively high concentration in biologically driven wastewater treatment operations, TCS cannot be ignored as a chemical stressor of resistance in the environment. Further context needs to be established to quantitatively determine the relative impacts of stressors that stimulate antibiotic resistance (e.g., antibiotics, antimicrobials, metals, etc.). A better understanding of the stressors for antibiotic resistance in each environmental compartment would allow research to focus treatment technologies and potential policy in areas of greatest concern.

For future research, a metagenomics approach would be appropriate for this type of study to identify a broader spectrum of resistance genes that might be affected by chronic exposure to TCS. In addition, isolating the role of mixed antibiotic and antimicrobials to determine synergistic or antagonistic effects could prove useful.

\section{Acknowledgements}

D. E. C. was funded by a grant from the Lafferty Family Foundation, the Water Quality Center, and the Dept. of Civil, Construction, and Environmental Engineering at Marquette University. M. C. was funded by a grant from the Lafferty Family Foundation. A. D. K. was funded by the University of Wisconsin Sea Grant Institute under grants from the National Sea Grant College Program, National Oceanic and Atmospheric Administration, U.S. Department of Commerce, and from the State of Wisconsin. Federal grant number (NA14OAR4170092), project number (R/HCE-20).

\section{References}

${ }^{1}$ Center for Disease Control, Antibiotic resistance threats in the United States, US Department of Health and Human Services, 2013, http://www.cdc.gov/drugresistance/pdf/ar-threats-2013-508.pdf, accessed January 2016.

${ }^{2}$ A. J. Alanis, Arch. Med. Res., 2005, 36, 697-705.

${ }^{3}$ M. R. Oggioni, L. Furi, J. R. Coelho, J.-Y. Maillard and J. L. Martínez, Expert Rev. Anti-Infect. Ther., 2013, 11, 363-366.

Environmental Science: Processes \& Impacts, Vol 18, No. 8 (2016): pg. 1060-1067. DOI. This article is @ Royal Society of Chemistry and permission has been granted for this version to appear in e-Publications@Marquette. Royal Society of Chemistry does not grant permission for this article to be further copied/distributed or hosted elsewhere without the express permission from Royal Society of Chemistry. 
NOT THE PUBLISHED VERSION; this is the author's final, peer-reviewed manuscript. The published version may be accessed by following the link in the citation at the bottom of the page.

${ }^{4}$ D. E. Carey and P. J. McNamara, Front. Microbiol., 2015, 5, DOI: 10.3389/fmicb.2014.00780.

${ }^{5}$ S. P. Yazdankhah, A. A. Scheie, E. A. Høiby, B.-T. Lunestad, E. Heir, T. $\varnothing$. Fotland, K. Naterstad and H. Kruse, Microb. Drug Resist., 2006, 12, 83-90.

${ }^{6}$ S. Saleh, R. N. S. Haddadin, S. Baillie and P. J. Collier, Lett. Appl. Microbiol., 2010, 52, 87-95.

7L. M. McMurry, M. Oethinger and S. B. Levy, Nature, 1998, 394, 531-532.

${ }^{8} \mathrm{~N}$. Brenwald and A. Fraise, J. Hosp. Infect., 2003, 55, 141-144.

${ }^{9}$ S. B. Levy, Symp. Ser.-Soc. Appl. Microbiol., 2002, 92, 65S-71S.

${ }^{10}$ R. P. Massengo-Tiass'e and J. E. Cronan, Cell. Mol. Life Sci., 2009, 66, 1507-1517.

${ }^{11}$ F. R. Champlin, M. L. Ellison, J. W. Bullard and R. S. Conrad, Int. J. Antimicrob. Agents, 2005, 26, 159-164.

${ }^{12}$ H. P. Schweizer, FEMS Microbiol. Lett., 2001, 202, 1-7.

${ }^{13}$ M. Braoudaki and A. C. Hilton, FEMS Microbiol. Lett., 2004, 235, 305-309.

${ }^{14}$ R. Chuanchuen, K. Beinlich, T. T. Hoang, A. Becher, R. R. KarkhoffSchweizer and H. P. Schweizer, Antimicrob. Agents Chemother., 2001, 45, 428-432.

${ }^{15}$ P. Sanchez, E. Moreno and J. L. Martinez, Antimicrob. Agents Chemother., 2005, 49, 781-783.

${ }^{16}$ K. a. G. Karatzas, M. A. Webber, F. Jorgensen, M. J. Woodward, L. J. V. Piddock and T. J. Humphrey, J. Antimicrob. Chemother., 2007, 60, 947-955.

${ }^{17}$ L. Birosová and M. Mikulásová, J. Med. Microbiol., 2009, 58, 436-441.

${ }^{18} \mathrm{C}$. Nietch, E. Quinlan, J. M. Lazorchak, C. A. Impellitteri, D. Raikow and D. Walters, Environ. Toxicol. Chem., 32, 2874-2887.

${ }^{19}$ J. H. Middleton and J. D. Salierno, Ecotoxicol. Environ. Saf., 2013, 88, 7988.

${ }^{20}$ A. Son, I. M. Kennedy, K. M. Scow and K. R. Hristova, J. Environ. Monit., 2010, 12, 1362-1367.

${ }^{21}$ A. J. Mcbain, R. G. Bartolo, C. E. Catrenich, D. Charbonneau, R. G. Ledder, B. B. Price and P. Gilbert, Appl. Environ. Microbiol., 2003, 69, 54335442.

22]. Heidler and R. U. Halden, Chemosphere, 2007, 66, 362-369.

${ }^{23}$ G.-G. Ying, X.-Y. Yu and R. S. Kookana, Environ. Pollut., 2007, 150, 300305.

${ }^{24}$ B. Pycke, I. Roll, B. Brownawell, C. A. Kinney, E. T. Furlong, D. W. Kolpin and R. U. Halden, Environ. Sci. Technol., 2014, 48, 7881-7890.

${ }^{25}$ P. J. McNamara, T. M. Lapara and P. J. Novak, Environ. Sci. Technol., 2014, 48, 7393-7400.

${ }^{26}$ United States Environmental Protection Agency, Targeted National Sewage Sludge Survey Sampling and Analysis Technical Report, 2009,

Environmental Science: Processes \& Impacts, Vol 18, No. 8 (2016): pg. 1060-1067. DOI. This article is @ Royal Society of Chemistry and permission has been granted for this version to appear in e-Publications@Marquette. Royal Society of Chemistry does not grant permission for this article to be further copied/distributed or hosted elsewhere without the express permission from Royal Society of Chemistry. 
http://www.epa.gov/sites/production/files/2015-

04/documents/targeted_national_sewage_sluldge_survey_sampling_a nd_analysis_technical_report_0.pdf, accessedJanuary 2016.

${ }^{27}$ A. E. Schauer-Gimenez, D. H. Zitomer, J. S. Maki and C. A. Struble, Water Res., 2010, 44, 3555-3564.

${ }^{28}$ B. F. G. Pycke, A. Crabb'e, W. Verstraete and N. Leys, Appl.

Environ. Microbiol., 2010, 76, 3116-3123.

${ }^{29}$ J. Jin, A. A. Guffanti, D. H. Bechhofer and T. A. Krulwich, J. Bacteriol., 2002, $184,4722-4732$.

30]. L. Rasmussen, D. A. Odelson and F. L. Macrina, J. Bacteriol., 1986, 168, 523-533.

${ }^{31}$ D. Mazel, Nat. Rev. Microbiol., 2006, 4, 608-620.

${ }^{32}$ D. E. Carey, D. H. Zitomer, K. Hristova, A. D. Kappell and P. J. McNamara, Environ. Sci. Technol., 2016, 50, 126-134.

${ }^{33}$ L. J. V. Piddock, Clin. Microbiol. Rev., 2006, 19, 382-402.

${ }^{34}$ B. Drury, J. Scott, E. J. Rosi-Marshall and J. J. Kelly, Environ. Sci. Technol., 2013, 47, 8923-8930.

${ }^{35}$ R. Lis, A. Rowhani-Rahbar and L. E. Manhart, Clin. Infect. Dis., 2015, 61, 418-426.

${ }^{36}$ S. Huang, J. Y. Li, J. Wu, L. Meng and C. C. Shou, World J. Gastroenterol., 2001, 7, 266-269.

${ }^{37}$ M. R. Redford, R. Ellis and C. J. Rees, J. Med. Microbiol., 2005, 54, 993995.

${ }^{38}$ S. H. Aliyu, R. K. Marriott, M. D. Curran, S. Parmar, N. Bentley, N. M. Brown, J. S. Brazier and H. Ludlam, J. Med. Microbiol., 2004, 53, 1029-1035.

${ }^{39}$ R. I. Aminov, Front. Cell. Infect. Microbiol., 2013, 3, DOI: 10.3389/fcimb.2013.00042.

${ }^{40}$ C. L. Nesbø, R. Kumaraswamy, M. Dlutek, W. F. Doolittle and J. Foght, Appl. Environ. Microbiol., 2010, 76, 4896-4900.

${ }^{41}$ E. R. K. Eribe and I. Olsen, Anaerobe, 2008, 14, 131-137.

${ }^{42}$ S. L. McLellan and A. M. Eren, Trends Microbiol., 2014, 22, 697-706.

${ }^{43}$ B. A. White, D. J. Creedon, K. E. Nelson and B. A. Wilson, Trends Endocrinol. Metab., 2011, 22, 389-393.

${ }^{44} \mathrm{~F}$. Baldacchino, V. Muenworn, M. Desquesnes, F. Desoli, T. Charoenviriyaphap and G. Duvallet, Parasite, 2013, 20, DOI: 10.1051/parasite/2013026.

${ }^{45}$ A. Takagaki, Y. Kato and F. Nanjo, Arch. Microbiol., 2014, 196, 681-695.

${ }^{46} \mathrm{~K}$. Yoneda, H. Chikumi, T. Murata, N. Gotoh, H. Yamamoto, H. Fujiwara, T. Nishino and E. Shimizu, FEMS Microbiol. Lett., 2005, 243, 125-131.

47]. Guo, Y. Peng, B.-J. Ni, X. Han, L. Fan and Z. Yuan, Microb. Cell Fact., 2015, 14, DOI: 10.1186/s12934-015-0218-4.

Environmental Science: Processes \& Impacts, Vol 18, No. 8 (2016): pg. 1060-1067. DOI. This article is @ Royal Society of Chemistry and permission has been granted for this version to appear in e-Publications@Marquette. Royal Society of Chemistry does not grant permission for this article to be further copied/distributed or hosted elsewhere without the express permission from Royal Society of Chemistry. 
NOT THE PUBLISHED VERSION; this is the author's final, peer-reviewed manuscript. The published version may be accessed by following the link in the citation at the bottom of the page.

${ }^{48}$ Y. Yang, K. Yu, Y. Xia, F. T. K. Lau, D. T. W. Tang, W. C. Fung, H. H. P. Fang and T. Zhang, Appl. Microbiol. Biotechnol., 2014, 98, 5709-5718.

${ }^{49}$ A. L. Smith, S. J. Skerlos and L. Raskin, J. Microb. Biotechnol., 2015, 8, 883-894.

${ }^{50}$ D. M. Stevenson and P. J. Weimer, Appl. Microbiol. Biotechnol., 2007, 75, 165-174.

${ }^{51}$ R. M. Petri, T. Schwaiger, G. B. Penner, K. A. Beauchemin, R. J. Forster, J. J. McKinnon and T. A. McAllister, Appl. Environ. Microbiol., 2013, 79, 3744-3755.

${ }^{52}$ T. D. Le Van, J. A. Robinson, J. Ralph, R. C. Greening, W. J. Smolenski, J. A. Leedle and D. M. Schaefer, Appl. Environ. Microbiol., 1998, 64, 34293436.

${ }^{53}$ S. Mao, R. Zhang, D. Wang and W. Zhu, BMC Vet. Res., 2012, 8, DOI: 10.1186/1746-6148-8-237.

${ }^{54}$ T. Zhang, X. X. Zhang and L. Ye, PLoS One, 2011, 6, DOI: 10.1371 /journal.pone.0026041.

${ }^{55}$ M. Dolejska, L. Villa, L. Poirel, P. Nordmann and A. Carattoli, J. Antimicrob. Chemother., 2012, 1407, 1-6, DOI: 10.1093/jac/dks357.

Figures

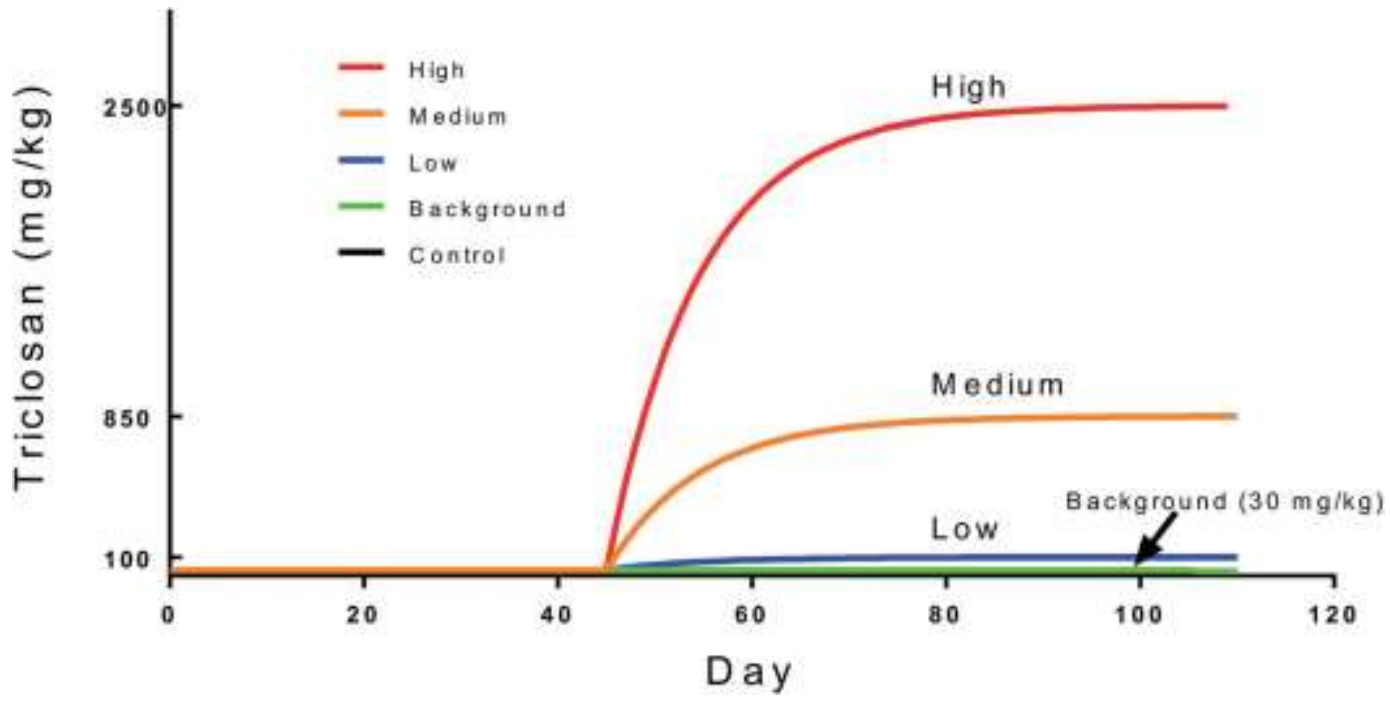

Fig. 1 Theoretical concentration of TCS in digester sets over the duration of the study. All digester sets (except for the control set operated at $0 \mathrm{mg} \mathrm{kg}^{-1}$ for the total 110 days), were operated at $30 \mathrm{mg} \mathrm{kg}^{-1}$ for the first 45 days.

Environmental Science: Processes \& Impacts, Vol 18, No. 8 (2016): pg. 1060-1067. DOI. This article is @ Royal Society of Chemistry and permission has been granted for this version to appear in e-Publications@Marquette. Royal Society of Chemistry does not grant permission for this article to be further copied/distributed or hosted elsewhere without the express permission from Royal Society of Chemistry. 
NOT THE PUBLISHED VERSION; this is the author's final, peer-reviewed manuscript. The published version may be accessed by following the link in the citation at the bottom of the page.

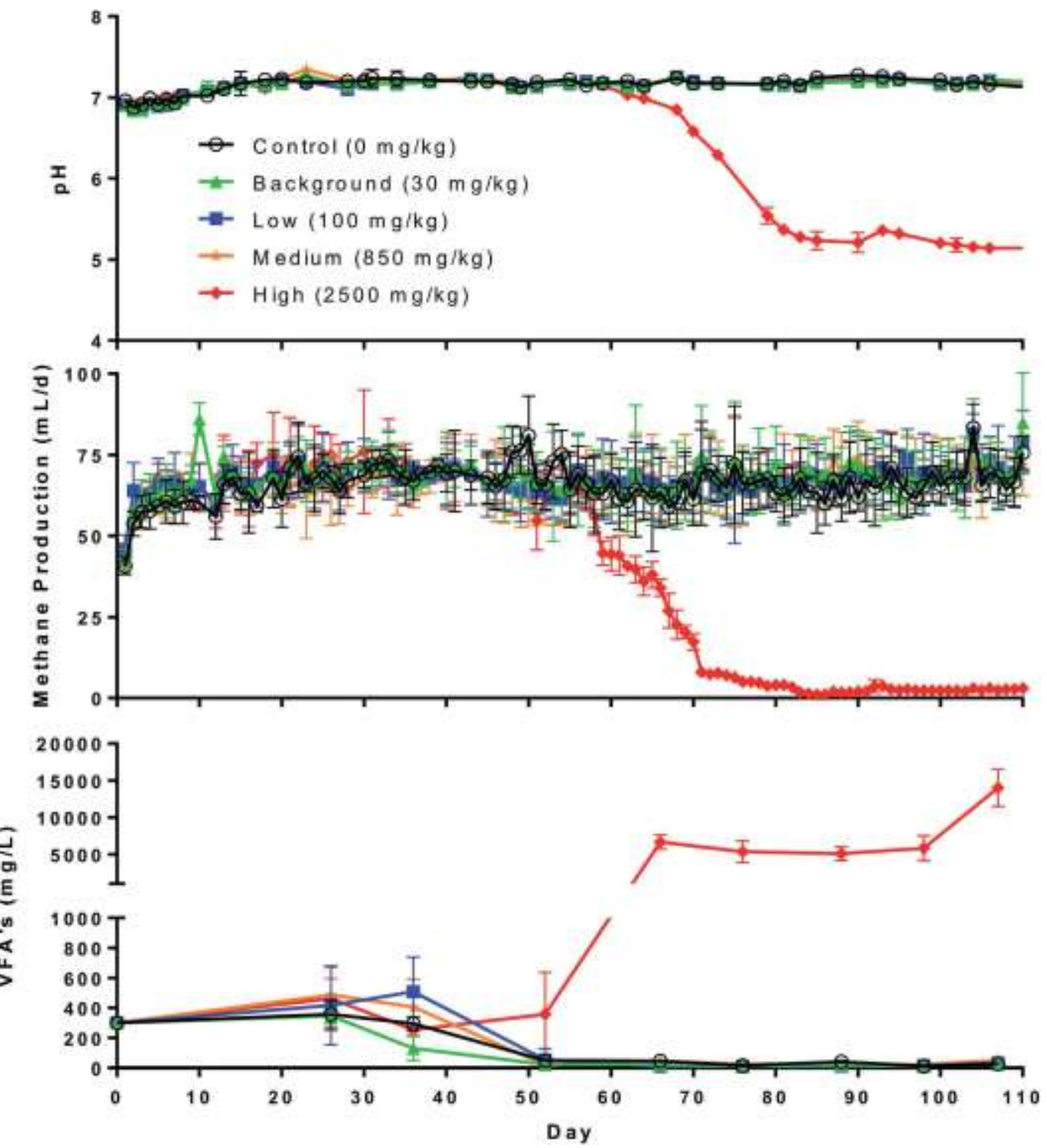

Fig. $2 \mathrm{pH}$, methane production and VFA concentrations. Error bars represent standard deviations ( $n=3$ for all points), and some error bars are small and not visible. VFAs include acetic acid, propionic acid, butyric acid, iso-butyric acid, valeric acid, and isovaleric acid.

Environmental Science: Processes \& Impacts, Vol 18, No. 8 (2016): pg. 1060-1067. DOI. This article is @ Royal Society of Chemistry and permission has been granted for this version to appear in e-Publications@Marquette. Royal Society of Chemistry does not grant permission for this article to be further copied/distributed or hosted elsewhere without the express permission from Royal Society of Chemistry. 
NOT THE PUBLISHED VERSION; this is the author's final, peer-reviewed manuscript. The published version may be accessed by following the link in the citation at the bottom of the page.
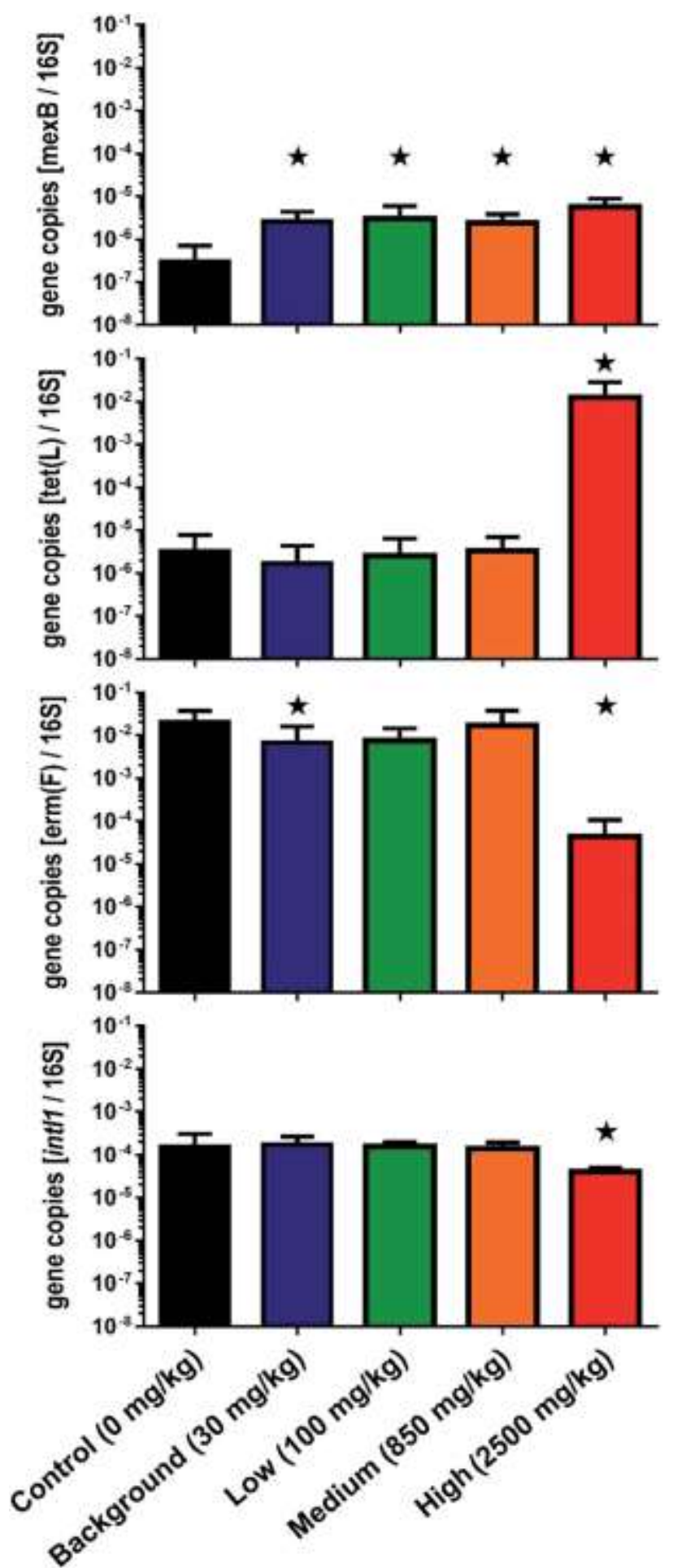

Fig. 3 Gene relative abundance on Day 110 normalized to 16S rRNA gene copy numbers (triplicate extraction from triplicate digesters, $n=9$ ). Error bars represent standard deviation. Statistical differences from the control $(p<0.05)$ are indicated with a star. Note differences of the 16S rRNA copies were not found to be statistically different among treatments (ANOVA, $p=0.46, n=9$, see ESI S7 + ).

Environmental Science: Processes \& Impacts, Vol 18, No. 8 (2016): pg. 1060-1067. DOI. This article is @ Royal Society of Chemistry and permission has been granted for this version to appear in e-Publications@Marquette. Royal Society of Chemistry does not grant permission for this article to be further copied/distributed or hosted elsewhere without the express permission from Royal Society of Chemistry. 
NOT THE PUBLISHED VERSION; this is the author's final, peer-reviewed manuscript. The published version may be accessed by following the link in the citation at the bottom of the page.

$$
\begin{aligned}
& \frac{\substack{\text { Day } \\
110}}{0--} \stackrel{\frac{0 y}{45}}{-} \text { Control } \\
& \triangle--4 \text { - Background } \\
& \text { ㅁ- - Low } \\
& x-x-\text { Medium }
\end{aligned}
$$

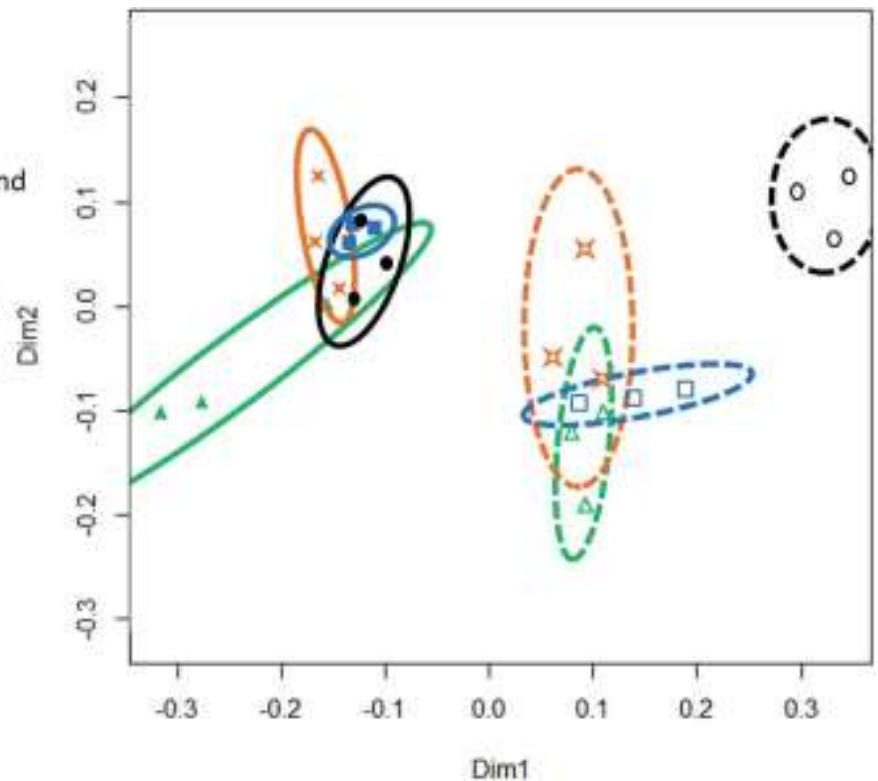

Fig. 4 NMDS ordination of genus level data at Day 45 and Day 110. The community structure data were gathered from Illumina partial sequencing of 16S rRNA gene. Ellipses represent $95 \%$ confidence intervals as calculated by the VEGAN package in R. High TCS treatment was not included because the community is starkly different and removes resolution from the plot. An NMDS plot including the 'high' digesters can be found in ESI S6. +

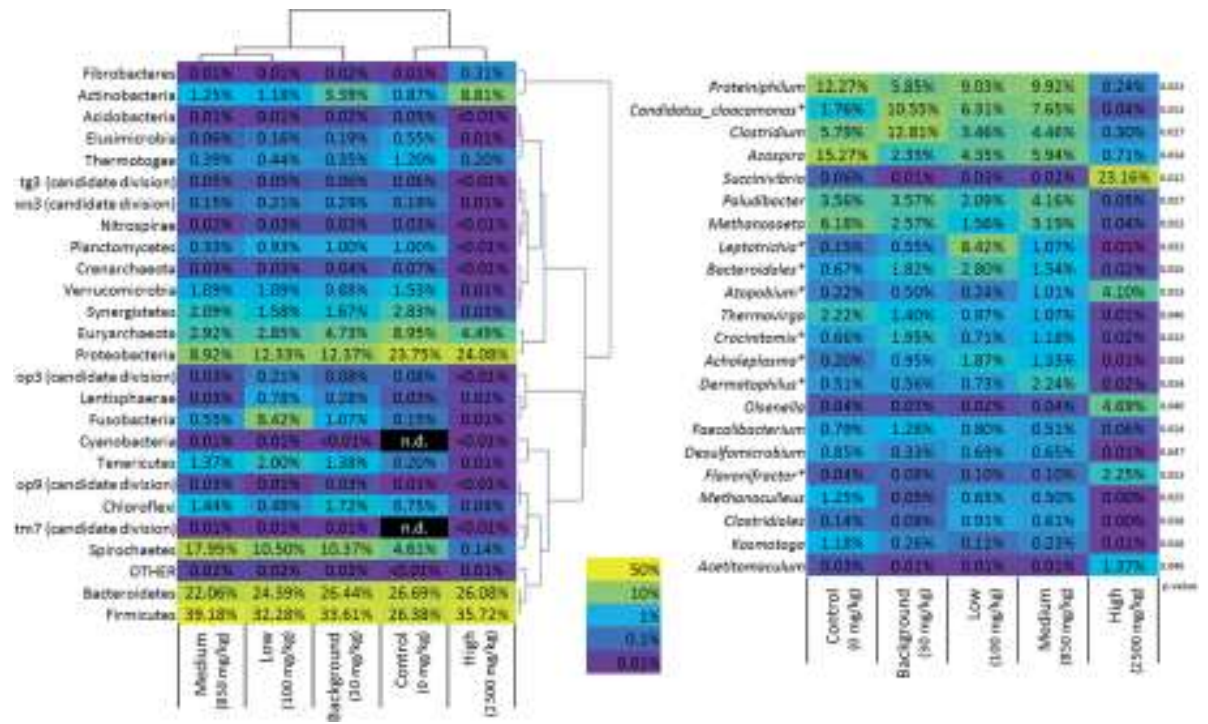

Fig. 5 [Left] Dual hierarchal clustering of phyla (average of the 3 digesters). Black boxes represent no detection (n.d.). [Right] Genera that show significant differences between reactor sets based on a Kruskal-Wallis test, and represent at least $1 \%$ of community in at least one reactor set (average of 3 digesters). The $p$-value from the statistical test is shown on the right. Genera with star next to the name represent genera which were selected for in the live reactors which contained TCS (i.e. background, low and medium).

Environmental Science: Processes \& Impacts, Vol 18, No. 8 (2016): pg. 1060-1067. DOI. This article is @ Royal Society of Chemistry and permission has been granted for this version to appear in e-Publications@Marquette. Royal Society of Chemistry does not grant permission for this article to be further copied/distributed or hosted elsewhere without the express permission from Royal Society of Chemistry. 